\title{
ITAMAR RABINOVICH
}

\section{The War for Lebanon, 1970-1983}

Archbishop Mitty High School

\author{
Media Center \\ 5000 Mitty Way \\ San Jose, CA 95129
}

Cornell University Press

ITHACA AND LONDON 


\subsection{2 \\ $R A B$}

\section{The War for Lebanon, 1970-1983}





\section{Copyright (C) 1984 by Cornell University Press}

All rights reserved. Except for brief quotations in a review, this book, or parts thereof, must not be reproduced in any form without permission in writing from the publisher. For information, address Cornell University Press, 124 Roberts Place, Ithaca, New York 14850.

First published 1984 by Cornell University Press.

Published in the United Kingdom by Cornell University Press Lid., London. Second printing 1984.

International Standard Book Number 0-8014-1627-2

Library of Congress Catalog Card Number 83-45935

Printed in the United States of America

Librarians: Library of Congress cataloging information appears on the last page of the book.

The paper in this book is acid-free and meets the guidelines for permanence and durability of the Committee on Production Guidelines for Book Longevity of the Council on Library Resources. 


\section{5 \\ 956.92 \\ RII iew}

In memory of my father, Gutman Rabinovich, 1913-1983 
